\title{
Decreased Threshold for Initiating L-T 4 Therapy in a Primary Care Population Over a 15-Year Period
}

\section{Haixia Guan}

Department of Endocrinology and Metabolism, The First Hospital of China Medical University, Shenyang, China

Review of: Medici BB, Nygaard B, La Cour JL, Grand MK, Siersma V, Nicolaisdottir DR, Lind B, Olivarius NF, Andersen CL 2019 Changes in prescription routines for treating hypothyroidism between 2001 and 2015-an observational study of 929,684 primary care patients in Copenhagen. Thyroid. Epub 2019 Apr 24. PMID: 31017048.

\section{SUMMARY}

\section{Background}

Increased focus on well-being and quality-of-life issues in the management of various diseases has led to the earlier diagnosis and subsequent treatment of hypothyroidism in many patients seen by primary care physicians. In order to weigh the risks and benefits of thyroid hormone replacement therapy, recommendations concerning the diagnosis of hypothyroidism and initiation of levothyroxine $\left(\mathrm{L}-\mathrm{T}_{4}\right)$ have been developed (1,2). The median serum TSH prompting the initiation of $\mathrm{L}-\mathrm{T}_{4}$ among over 52,000 individuals in the United Kingdom decreased from $8.7 \mathrm{mIU} / \mathrm{L}$ to $7.9 \mathrm{mIU} / \mathrm{L}$ between 2001 and 2009 (3), thus raising concerns about $\mathrm{L}-\mathrm{T}_{4}$ overuse and its potential harm. The current study (4) was performed to assess changes in thyroid hormone prescriptions for the treatment of hypothyroidism among general practitioners in Copenhagen between 2001 and 2015.

\section{Methods}

This is a retrospective analysis of a large database of primary care patients in Copenhagen, Denmark. Composition of the population and iodine fortification during the studied period were unchanged. Serum TSH measurements performed at the one laboratory utilized by all general practitioners (GPs) in Copenhagen were retrieved. The laboratory database was linked to three nationwide reg- istration systems; relevant information concerning vital status, diagnoses, and medication prescriptions were collected. Measurements of TSH were excluded from the analysis if they were: (i) from individuals with a diagnosis of hyperthyroidism, thyroid cancer, or pituitary disease; (ii) assayed within 6 months after a prescription was issued of a medication that may interfere with thyroid function; (iii) assayed within 12 months before or after a registered birth or abortion; or (iv) from patients with a redeemed $\mathrm{L}-\mathrm{T}_{4}$ prescription within the previous 3 years of each TSH assay. For each year, both the median TSH and the estimated treatment threshold

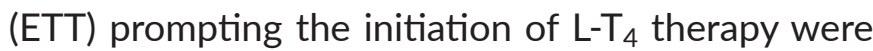
calculated. The ETTs were computed from all TSH measurements performed in that year, representing the TSH concentration in which the estimated probability of starting $\mathrm{L}-\mathrm{T}_{4}$ therapy was $50 \%$.

\section{Results}

A total of 929,684 individuals with 2,975,277 serum TSH measurements were included in the study. Between 2001 and 2015, the number of individuals with a TSH measurement increased by $146 \%$, corresponding to $164 \%$ more TSH assays conducted. Median TSH in the data set increased from $1.3 \mathrm{mU} / \mathrm{L}$ in 2001 to $1.6 \mathrm{mU} / \mathrm{L}$ in 2015. In this primary care population, $2.24 \%$ of unique individuals ( $n=20,862$ ) 
started L-T 4 therapy 21,188 times between 2001 and 2015. The female:male ratio of individuals initiating $\mathrm{L}-\mathrm{T}_{4}$ therapy remained approximately $6: 1$. The total number of patients initiating $\mathrm{L}-\mathrm{T}_{4}$ therapy during this period increased from 786 to 1825 (132\%), with numbers being essentially stable between 2010 and 2015. In 2001, the median TSH at L-T 4 therapy initiation was $10 \mathrm{mU} / \mathrm{L}$ (interquartile range, 5.2-29.7), while in 2015, it decreased to $6.8 \mathrm{mU} / \mathrm{L}$ (interquartile range, 5.1-11). The median TSH that led to $\mathrm{L}-\mathrm{T}_{4}$ therapy among patients $>80$ years old also declined from $13.5 \mathrm{mU} / \mathrm{L}$ to $7.3 \mathrm{mU} / \mathrm{L}$.

The ETT for starting $\mathrm{L}-\mathrm{T}_{4}$ fell from $28.3 \mathrm{mU} / \mathrm{L}$ (95\% confidence interval, 21.0-40.2) in 2001 to 14.2 $\mathrm{mU} / \mathrm{L}$ (95\% confidence interval, 12.0-18.0) in 2007 and remained steady thereafter. Among patients who started on $\mathrm{L}^{-\mathrm{T}_{4}}$ therapy in $2001,26 \%, 5 \%$, and
$19 \%$ had a TSH of 5-10 mU/L, 2.5 $-5 \mathrm{mU} / \mathrm{L}$ and $<2.5$ $\mathrm{mU} / \mathrm{L}$, respectively, while in 2015 , the percentages were $49 \%, 13 \%$, and $12 \%$. During the entire study period, $50 \%$ of patients started $\mathrm{L}^{-\mathrm{T}_{4}}$ with a single TSH measurement above $5 \mathrm{mU} / \mathrm{L}$.

\section{Conclusions}

The median serum TSH threshold for starting $\mathrm{L}^{-\mathrm{T}_{4}}$ therapy decreased in a sizable primary care patient population in Copenhagen between 2001 and 2015. Growing numbers of total TSH measurements and a declining $\mathrm{TSH}$ threshold for $\mathrm{L}^{-\mathrm{T}_{4}}$ initiation did not lead to a similar increase in new prescriptions, suggesting that few persons with hypothyroidism remained undiagnosed. The majority of patients started on $\mathrm{L}^{-\mathrm{T}_{4}}$ therapy without a repeat TSH measurement, thereby increasing the risks of both potential unnecessary treatment and overtreatment.

\section{COMMENTARY}

This study (4) suggests that GPs in this sample have increasingly considered the known unfavorable impact of thyroid dysfunction on overall health. Unfortunately, this awareness has likely resulted in an excessive number of serum TSH measurements being performed, as the increase in number of TSH examinations conducted between 2010 and 2015 did not detect increasingly more hypothyroid patients during this time frame. Further, the tendency for inappropriately initiating $\mathrm{L}-\mathrm{T}_{4}$ therapy in this primary care population may place patients at risk for $\mathrm{L}_{-} \mathrm{T}_{4}$ overuse and possible harm.

The falling threshold of serum TSH for starting $\mathrm{L}-\mathrm{T}_{4}$ therapy, as well as the rising percentage of patients being treated for a TSH of 5-10 $\mathrm{mU} / \mathrm{L}$, indicate the need for reemphasizing management strategies for subclinical hypothyroidism (SCHypo). Key clinical points include the following. First, appropriate diagnosis of SCHypo requires ruling out a transient increase in serum TSH by repeating the measurement after 2 to 3 months. Second, in up to $46 \%$ of patients with $\mathrm{SCHypo}$ who have a TSH level of $<7 \mathrm{mU} / \mathrm{L}$, the TSH level normalizes within 2 years (5). Third, in patients who have TSH levels of $<10 \mathrm{mU} / \mathrm{L}$ or who are $>70$ years of age, treatment decisions should be based on individual patient factors (e.g., symptoms of hypothyroidism, a positive test for thyroid peroxidase antibodies, or cardiac risk factors). Fourth, randomized, controlled trials have shown that treatment of $\mathrm{SCHypo}$ with $\mathrm{L}-\mathrm{T}_{4}$ provides no apparent benefits in older persons ( $\geq 65$ years) (6), does not improve quality of life, thyroid-related symptoms (7), or IQ in offspring (8). Lastly, ongoing $\mathrm{L}-\mathrm{T}_{4}$ treatment in patients with heart failure is associated with an increased risk of all-cause mortality, cardiovascular death, and major cardiovascular events (9). Thus, the management and initiation of potential $\mathrm{L}_{-} \mathrm{T}_{4}$ treatment in patients with $\mathrm{SCHypo}$ requires careful decision making. 
Future studies in the general population are needed to reveal whether initiating $\mathrm{L}^{-\mathrm{T}_{4}}$ at a TSH level of $<5 \mathrm{mU} / \mathrm{L}$ might be indicated under certain circum- stances, and to evaluate health outcomes and health care costs incurred by the decreasing threshold for starting thyroid hormone replacement therapy.

\section{REFERENCES}

1. Jonklaas J, Bianco AC, Bauer AJ, Burman KD, Cappola AR, Celi FS, Cooper DS, Kim BW, Peeters RP, Rosenthal MS, et al 2014 Guidelines for the treatment of hypothyroidism: prepared by the American Thyroid Association task force on thyroid hormone replacement. Thyroid 24:1670-1751.

2. Pearce SH, Brabant G, Duntas LH, Monzani F, Peeters RP, Razvi S, Wemeau JL. 20132013 ETA Guideline: management of subclinical hypothyroidism. Eur Thyroid J 2:215-228.

3. Taylor PN, lqbal A, Minassian C, Sayers A, Draman MS, Greenwood R, Hamilton W, Okosieme O, Panicker V, Thomas SL, Dayan C 2014 Falling threshold for treatment of borderline elevated thyrotropin levels-balancing benefits and risks: evidence from a large community-based study. JAMA Intern Med 174:32-39.

4. Medici BB, Nygaard B, La Cour JL, Grand MK, Siersma V, Nicolaisdottir DR, Lind B, Olivarius NF, Andersen CL 2019 Changes in prescription routines for treating hypothyroidism between 2001 and 2015-an observational study of 929,684 primary care patients in Copenhagen. Thyroid. Epub 2019 Apr 24.

5. Peeters RP. Subclinical hypothyroidism 2017 N Engl J Med 376(26):2556-2565.
6. Stott DJ, Rodondi N, Kearney PM, Ford I, Westendorp RGJ, Mooijaart SP, Sattar N, Aubert CE, Aujesky D, Bauer DC, et al. 2017 Thyroid hormone therapy for older adults with subclinical hypothyroidism. N Engl J Med 376:2534-2544.

7. Feller M, Snel M, Moutzouri E, Bauer DC, de Montmollin M, Aujesky D, Ford I, Gussekloo J, Kearney PM, Mooijaart S, et al. 2018 Association of thyroid hormone therapy with quality of life and thyroid-related symptoms in patients with subclinical hypothyroidism: a systematic review and metaanalysis. JAMA 320:1349-1359.

8. Casey BM, Thom EA, Peaceman AM, Varner MW, Sorokin Y, Hirtz DG, Reddy UM, Wapner RJ, Thorp JM Jr, Saade G, et al. 2017 Treatment of subclinical hypothyroidism or hypothyroxinemia in pregnancy. N Engl J Med 376:815-825.

9. Einfeldt MN, Olsen AS, Kristensen SL, Khalid U, Faber J, Torp-Pedersen C, Gislason GH, Selmer C 2019 Long-term outcome in patients with heart failure treated with levothyroxine: an observational nationwide cohort study. J Clin Endocrinol Metab 104:1725-1734. 